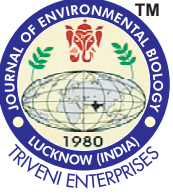

DOI : http://doi.org/10.22438/jeb/39/5/MRN-427

\title{
Determining the effect of system parameters on ultrasonic water disinfection and enhancing its efficiency with a hybrid application
}

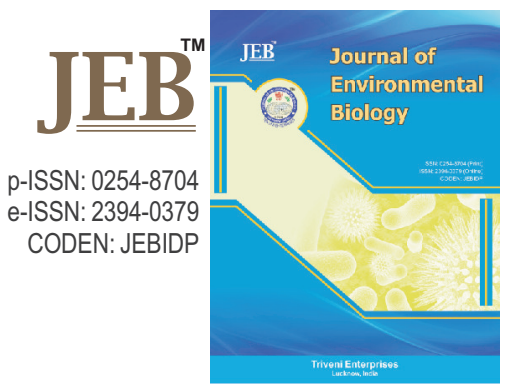

Authors Info

\section{F.B. Karel*}

Department of Environmental Engineering, Anadolu University, Eskisehir - 26555, Turkey

*Corresponding Author Email : fbayrakci@anadolu.edu.tr

Key words

Escherichia coli

Hydrogen peroxide

Media ions

Ultrasound

Water disinfection

Publication Info

Paper received : 05.08.2016

Revised received : 14.03.2017

Re-revised received : 23.06 .2017

Accepted : 27.12.2017

\section{Abstract}

Aim: The study was carried out to investigate the ultrasonic disinfection efficiency for water treatment, which is one of the most remarkable technologies among the new disinfection alternatives.

Methodology: The disinfection of Escherichia coli, as an indicator microorganism of fecal pollution in water, was performed with ultrasound. Ultrasonic frequency, presence of dominant media ions (sulphate, nitrate and bicarbonate) at different concentrations and dissolved nitrogen gas at three flow rates were mainly investigated as system parameters in an ultrasonic batch type reactor. Hydrogen peroxide was used to enhance the ultrasonic disinfection efficiency over a shorter inactivation period at three different concentrations

Results: The highest Escherichia coli inactivation ( $5 \mathrm{log}$ ) occurred at $28 \mathrm{kHz}$ frequency, and sulphate and bicarbonate ions accelerated the ultrasonic disinfection efficiency when increasing their concentration in water. In addition, while the nitrate ion had no significant effect on the ultrasound process, dissolved nitrogen gas increased the bacterial inactivation with increasing flow rates. In the hybrid disinfection application of ultrasound and hydrogen peroxide, increasing $\mathrm{H}_{2} \mathrm{O}_{2}$ concentration provided more efficient bacterial inactivation over a shorter disinfection period.

Interpretation: Disinfection with ultrasound and hydrogen peroxide was successfully performed in water treatment, and their hybrid application supplied more efficient bacterial inactivation over a shorter disinfection period due to their synergistic effect.

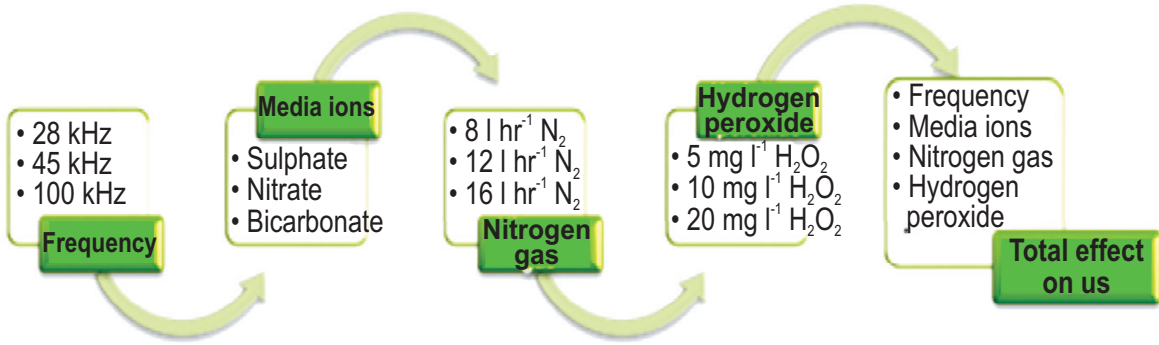

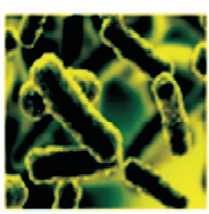

Ultrasonic Disinfection Process

working solution

$1 \times 105 \mathrm{CFU} \mathrm{ml}^{-1}$ Escherichia coli

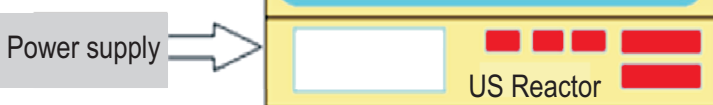

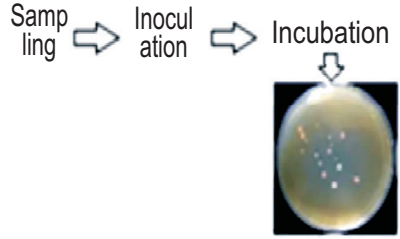

The number of bacteria after disinfection process 


\section{Introduction}

Pathogenic microorganisms must be disinfected with a suitable treatment process to avoid health risks, such as epidemic disease and infection, which can result from fecal contamination in water (Krishnan et al., 2007; LeChevallier and Au, 2013; Gray, 2014). Different treatment processes are performed to supply potable water for public use (Arbuckle, 1976).

Some of the conventional disinfections methods for safe drinking water are chlorination (Spellman 1999), potassium permanganate (Chen and Yeh, 2005), hydrogen peroxide $\left(\mathrm{H}_{2} \mathrm{O}_{2}\right)$ (Drogui et al., 2001), bromate (Von Gunten, 2003) and iodate. Ozone (Von Gunten and Pinkernell, 2000), UV radiation (Li et al., 2008), ultrafiltration (Arnal et al., 2004), and ultrasound (Phull et al., 1997; Ince and Belen, 2001; Mason et al., 2003; Wu et al., 2013) are alternative disinfection technologies to conventional methods.

Conventional disinfection methods have some disadvantages therefore, a search for new disinfection alternatives has been ongoing for the last several decades to overcome the drawbacks of conventional methods and attain adequate disinfection efficiency with changing water quality (Fiessinger et al., 1981; Spellman, 1999; Nair et al., 2006; Prakash and Somashekar, 2006).

Ultrasound is described as a frequency between $18 \mathrm{kHz}$ and $1 \mathrm{MHz}$, and its bacterial inactivation effect occurs by means of three system, which are bacterial cell barrier depletion, separation of bacterial cluster and hydrogen peroxide formation through a sono-chemical process, so resulting in the collapse of transit ultrasonic cavitation bubbles with high energy and pressure release (Joyce et al., 2003; Mason et al., 2003; Wu et al., 2013). Mason et al. (2003) performed biological water decontamination with ultrasound and chlorination. They reported that ultrasound with chlorination was successfully used for largescale industrial water disinfection even though previous studies pointed out that ultrasonic disinfection alone was a costly method. Blume and Neis (2004) conducted ultrasonic pre-treatment for UV application to enhance the efficiency of UV radiation in the presence of particulate matter in water. Their study demonstrated that ultrasound reduced the average particulate diameter and increased the bacterial inactivation. They suggested that ultrasonic pre-treatment would be cost-effective in water with high turbidity.

Previous research (Joyce et al., 2003; Mason et al., 2003; Mason et al., 2003) has predicted that the energy requirement also increases during ultrasonic disinfection due to large power consumption, especially for industrial usage of ultrasound. Therefore, this study aimed to enhance the efficiency of ultrasonic disinfection with hydrogen peroxide. To attain adequate Escherichia coli inactivation in an ultrasonic reactor, three different ultrasonic frequencies were used, and the effects of dominant media ions in the water (sulfate, bicarbonate and nitrate) and different dissolved nitrogen flow rates applied on ultrasound process were examined to optimize the ultrasonic system parameters. To achieve more efficient bacterial inactivation over a shorter disinfection period, a hybrid application was performed for water treatment using the synergetic effect of ultrasound and hydrogen peroxide.

\section{Materials and Methods}

Ultrasonic disinfection studies: Disinfection studies were performed in a W-113 Ultrasonic multi-cleaner (Honda Electronics Co., Ltd., Aichi, Japan) using batch flow condition. This batch type of ultrasonic reactor was operated at ultrasonic frequencies of 28,45 and $100 \mathrm{kHz}$ and at a power of $100 \mathrm{~W}$. An Escherichia coli working solution of $100 \mathrm{ml}$ and a concentration of $1 \times 10^{5} \mathrm{CFU} \mathrm{ml}{ }^{-1}$ was disinfected at three ultrasonic frequencies. The disinfection studies were carried out in a sterile cabinet (Heraeus KSP-18 Class II) at room conditions.

Ultrasonic disinfection studies were performed for a contact time of $60 \mathrm{~min}$. The bacterial concentration was determined with a simple plate count method during all disinfection studies using serial dilution of the samples. All the samples were inoculated on plate count agar (PCA, Merck KGgAGermany) solid media, and the plates were incubated at $37^{\circ} \mathrm{C}$ for 18-24 hrs (Giannakis et al., 2015). The bacterial inactivation ratio was calculated as the difference between the initial bacterial concentration and final bacterial concentration for each disinfection study. The disinfection efficiencies of systems were determined with the average bacterial concentration of samples taking into account Eq. 1 accounting to logarithmic term.

$$
E(\log )=\log \left(C_{0}-C_{t}\right)
$$

Where, $\mathrm{E}(\mathrm{log})=$ Disinfection efficiency in logarithmic term; $\mathrm{C}_{0}=$ Initial average bacterial concentration $\left(\mathrm{CFU} \mathrm{ml^{-1 }}\right)$ and $\mathrm{C}_{\mathrm{t}}=$ Average bacterial concentration at time $\left(\mathrm{CFU} \mathrm{ml}^{-1}\right)$.

Media ions on the ultrasonic disinfection process: The effects of media ions were examined for sulphate, bicarbonate and nitrate ions listed as the dominant ions in water bodies. These ions were added as $\mathrm{Na}_{2} \mathrm{SO}_{4}$ (Merck KGgA, Germany), $\mathrm{NaHCO}_{3}$ (Merck KGgA, Germany) and $\mathrm{NaNO}_{3}$ (Merck KGgA, Germany) in the ultrasonic system. The effect of each ion at two concentrations was determined using $200 \mathrm{mg} \mathrm{l}^{-1} \mathrm{SO}_{4}^{-2}, 100 \mathrm{mg} \mathrm{l}^{-1} \mathrm{SO}_{4}^{-2}, 50 \mathrm{mg} \mathrm{l}^{-1}$ $\mathrm{HCO}_{3} ; 25 \mathrm{mgl}^{-1} \mathrm{HCO}_{3} ; 25 \mathrm{mg} \mathrm{l}^{-1} \mathrm{NO}_{3}^{-}$and $50 \mathrm{mg} \mathrm{l}^{-1} \mathrm{NO}_{3}$. These concentrations were determined based on the water limitation of these ions' concentration. The disinfection studies were repeated by adding these ions to the system at ultrasonic frequencies showing the highest bacterial inactivation.

Dissolved nitrogen gas on the ultrasonic disinfection process: The effect of dissolved nitrogen gas in water was 
investigated with $\mathrm{N}_{2}$ flow rates of $8 \mathrm{I} \mathrm{hr^{-1 }}, 12 \mathrm{I} \mathrm{hr}$ and $16 \mathrm{l} \mathrm{hr^{-1 }}$. A working solution was saturated with a maximum flow rate of nitrogen gas for 5 min to determine the effect of only nitrogen dissolved in water and without other gases (these other gases can enter from air to the working solution). The disinfection studies were performed with three different flow rates, and the effect of dissolved nitrogen gas on bacterial inactivation was determined.

Escherichia coli disinfection with hydrogen peroxide: Hydrogen peroxide is a strong oxidizing agent and has a bacterial inactivation effect. The bacterial inactivation effect of hydrogen peroxide on Escherichia coli was examined for concentrations of $5 \mathrm{mg} \mathrm{l}^{-1}, 10 \mathrm{mg} \mathrm{l}^{-1}$ and $20 \mathrm{mg} \mathrm{l}^{-1}$ in the working solution. Hydrogen peroxide stock solution of $500 \mathrm{mg} \mathrm{l}^{-1}, 1000 \mathrm{mg} \mathrm{l}^{-1}$ and $2000 \mathrm{mg} \mathrm{l}^{-1}$ carring out the hydrogen peroxide disinfection studies. These working concentrations of hydrogen peroxide $\left(5 \mathrm{mg} \mathrm{I}^{-1}, 10 \mathrm{mg} \mathrm{I}^{-1}\right.$ and $20 \mathrm{mg} \mathrm{l}^{-1}$ ) were set in the working solution using $1 \mathrm{ml}$ of suitable stock solution of each concentration. The disinfection studies were performed with three different concentrations of hydrogen peroxide, and the effect of bacterial inactivation was determined in the same working solution at similar flow conditions and contact time.

Escherichia coli disinfection with hydrogen peroxide and ultrasound: The hybrid disinfection studies of ultrasound and hydrogen peroxide were conducted in an ultrasonic reactor with $\mathrm{H}_{2} \mathrm{O}_{2}$ concentrations of $5 \mathrm{mg} \mathrm{l}^{-1}, 10 \mathrm{mg} \mathrm{l}^{-1}$ and $20 \mathrm{mg} \mathrm{l}^{-1}$ and applying a $28 \mathrm{kHz}$ ultrasonic frequency. To determine the synergetic effect of $\mathrm{H}_{2} \mathrm{O}_{2}$, the US disinfection studies were repeated with similar conditions as the previous disinfection process.

Simultaneous effect of media ions, dissolved nitrogen gas and hydrogen peroxide: The simultaneous effect of media ions and dissolved nitrogen gas was determined by adding of $200 \mathrm{mgl}$ ${ }^{1} \mathrm{SO}_{4}^{-2}, 50 \mathrm{mg} \mathrm{l}^{-1} \mathrm{HCO}_{3}^{-}, 50 \mathrm{mgl}^{-1} \mathrm{NO}_{3}, 10 \mathrm{mg} \mathrm{l}^{-1} \mathrm{H}_{2} \mathrm{O}_{2}$, and $16 \mathrm{hr}^{-1}$ nitrogen gas to the ultrasonic system at $28 \mathrm{kHz}$ frequency. The concentrations with highest bacterial inactivation ratio were added to the ultrasonic reactor, and disinfection studies were repeated.

\section{Results and Discussion}

The effect of ultrasonic frequency on Escherichia coli disinfection process at an average of $1 \times 10^{5} \mathrm{CFU} \mathrm{ml} \mathrm{I}^{-1}$ is shown in Fig. 1. The results of ultrasonic disinfection studies indicated maximum bacterial inactivation rate at an ultrasonic frequency of $28 \mathrm{kHz}$.

In the present study, the highest inactivation efficiency of Escherichia coli was determined at an ultrasonic frequency application of $28 \mathrm{kHz}$ after a 60 min disinfection period as bacterial inactivation ratio is dependent on the mechanical disruption effect on the cell membrane from ultrasonic frequency.
The result of ultrasonic disinfection studies can be explained by high-power ultrasound frequencies, which are described as using low ultrasonic frequencies between $16 \mathrm{kHz}$ and $100 \mathrm{kHz}$ because high-power ultrasound is more effective than high-frequency $(500 \mathrm{kHz}-1 \mathrm{MHz})$ ultrasound when performing bacterial inactivation. This phenomenon was stated in previous research that investigated bacterial disinfection with ultrasound. Joyce et al. (2003) investigated ultrasonic disinfection performed at frequencies of $20 \mathrm{kHz}$ and $38 \mathrm{kHz}$ and observed an increased kill percentage of Bacillus species compared to that observed at frequencies of $512-850 \mathrm{kHz}$. Gomez-Lopez et al. (2014) investigated Escherichia coli disinfection and indicated that high power density provides high bacterial inactivation with a simultaneous temperature effect. The chemical effects of highfrequency ultrasound leading to thermal decomposition of water molecules into $\mathrm{OH}^{-}$and $\mathrm{H}^{+}$radicals was probably insufficient for the inactivation of Escherichia coli, although the physical effect of low-frequency ultrasound enhanced the efficiencies of bacterial inactivation.

Joyce et al. (2003) applied disinfection with ultrasound to Bacillus subtilis and researched the effect of ultrasonic frequency and applied power on the ultrasonic disinfection process. They indicated that ultrasonic frequencies of 20 and $38 \mathrm{kHz}$, i.e., lower frequency ultrasound, demonstrated the highest bacterial inactivation ratio. Scherba et al. (1991) performed Escherichia coli disinfection with different ultrasonic frequencies. They determined that increasing the contact time increased bacterial inactivation, but increasing the ultrasonic density had no meaningful effect on the inactivation rate.

Ince and Belen (2001) showed that the Escherichia coli concentration was reduced at an ultrasonic frequency of $20 \mathrm{kHz}$ in water when ceramic powder, metallic zinc powder and granule active carbon was added to the ultrasonic system. They stated that each additional material accelerated the formation of cavitation during the sonication period. Hulsmans et al. (2010) examined an ultrasonic water disinfection system and claimed that a rapid bacterial inactivation ratio, in the case of an extreme bacterial concentration, was obtained with a high water flow rate, power density, and energy gained under continuous flow conditions.

The disinfection experiments were performed at an ultrasonic frequency of $28 \mathrm{kHz}$ at $100 \mathrm{~W}$, which showed highest inactivation yield in ultrasonic disinfection studies. The effect of media ions on the ultrasonic system is shown in Fig. 2.

The Escherichia coli inactivation rates via disinfection using $200 \mathrm{mg} \mathrm{l}^{-1} \mathrm{SO}_{4}^{-2}, 100 \mathrm{mg} \mathrm{l}^{-1} \mathrm{SO}_{4}^{-2}, 50 \mathrm{mg} \mathrm{l}^{-1} \mathrm{HCO}_{3}^{-}, 25 \mathrm{mg} \mathrm{l}^{-1}$ $\mathrm{HCO}_{3}^{-}, 25 \mathrm{mg} \mathrm{l}^{-1} \mathrm{NO}_{3}^{-}$and $50 \mathrm{mg} \mathrm{l}^{-1} \mathrm{NO}_{3}^{-}$in an ultrasonic reactor were nearly $5 \log , 4 \log , 5 \log , 3 \log , 2 \log$ and $1.9 \log$, respectively, although the maximum bacterial inactivation was $3.1 \log$ in the ultrasonic disinfection studies without any addition. Addition of 


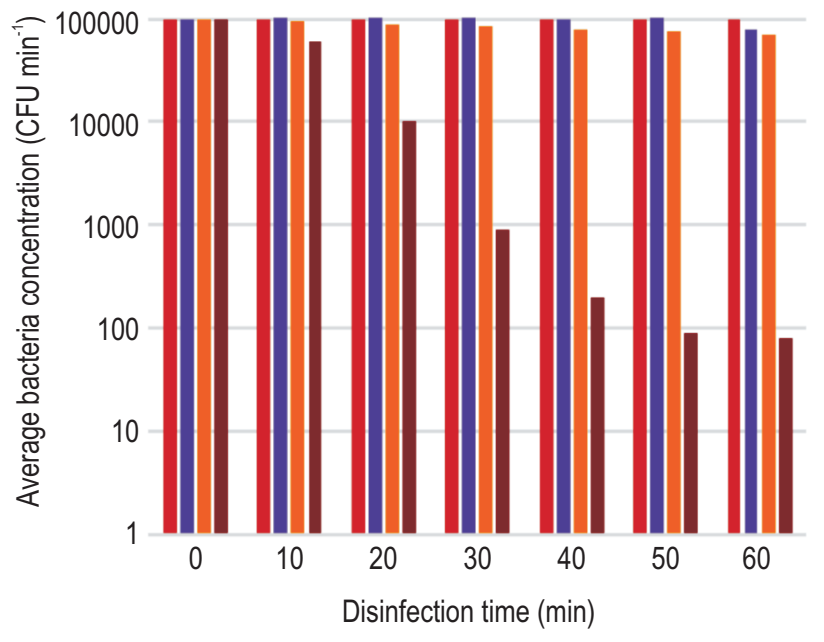

- Control $\quad \square 100 \mathrm{kHz} \quad \square=45 \mathrm{kHz} \quad \square 28 \mathrm{kHz}$

Fig. 1 : Effect of ultrasonic frequency on the Escherichia coli disinfection process at a concentration of $1 \times 10^{5} \mathrm{CFU} \mathrm{ml^{-1 }}$

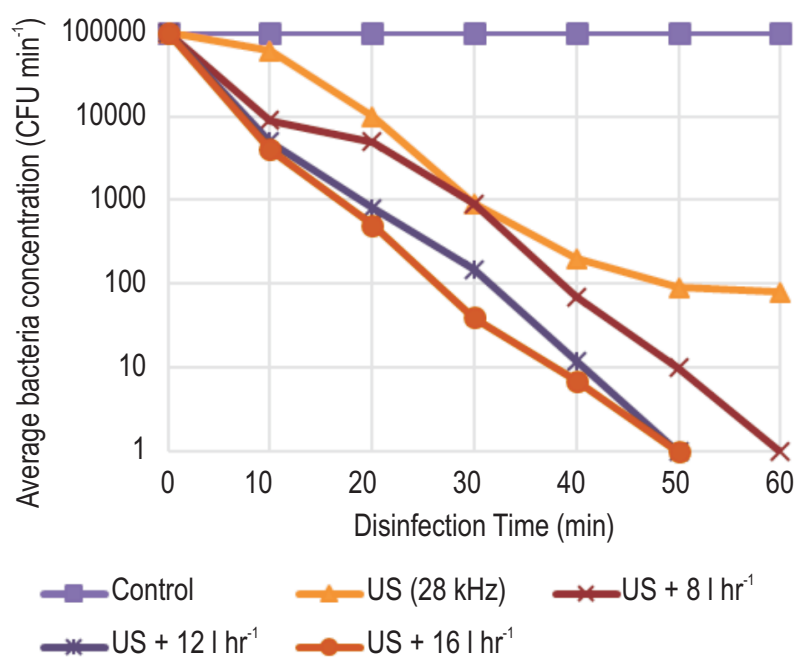

Fig. 3 : Effect of dissolved nitrogen gas on the ultrasonic disinfection process ( $28 \mathrm{kHz}$ of ultrasonic frequency and $100 \mathrm{~W}$ of power; $1 \times 10^{5} \mathrm{CFU}$ $\mathrm{ml}^{-1}$ Escherichia coliand a 60-min disinfection period)

some media ions to the ultrasonic system increased the bacterial inactivation efficiency as weak points for cavitation initiator was created by these ions.

For this reason, media ions such as sulphate (Jiang et al., 2006), bicarbonate (Jiang et al., 2006) and nitrate (Tauber et al., 2000; Silva et al., 2007) in ultrasonic disinfection must be considered. It is acknowledged that a high amount of cavitation is created by the effect of forming weak points for the cavitation initiator by ions associated with the system (Joyce et al., 2003;

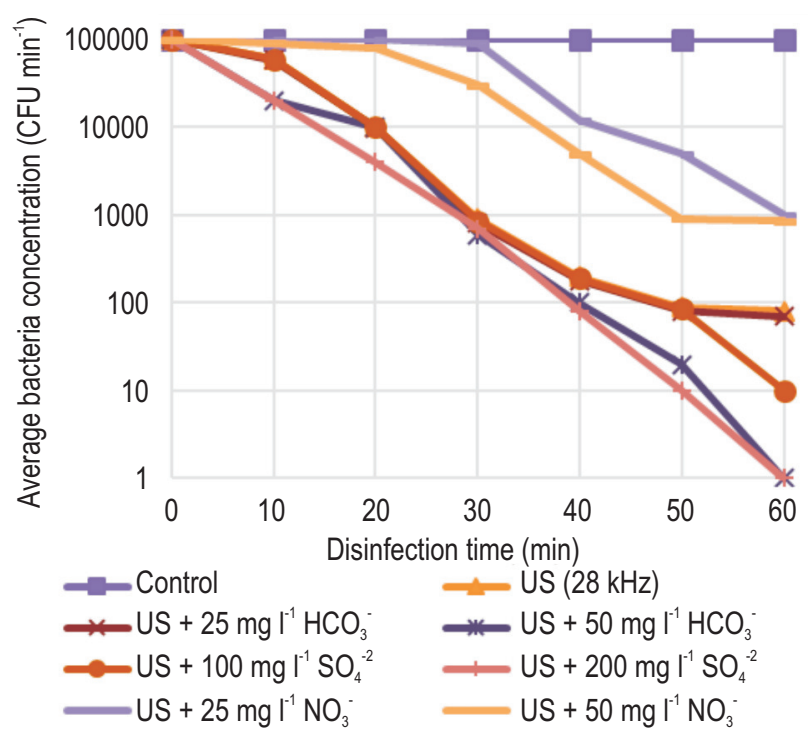

Fig. 2 : Effect of media ions on the ultrasonic disinfection process (ultrasonic frequency of $28 \mathrm{kHz}$ and $100 \mathrm{~W}$ of power; $1 \times 10^{5} \mathrm{CFU} \mathrm{ml}{ }^{-1}$ of Escherichia coliand a 60-min disinfection period)

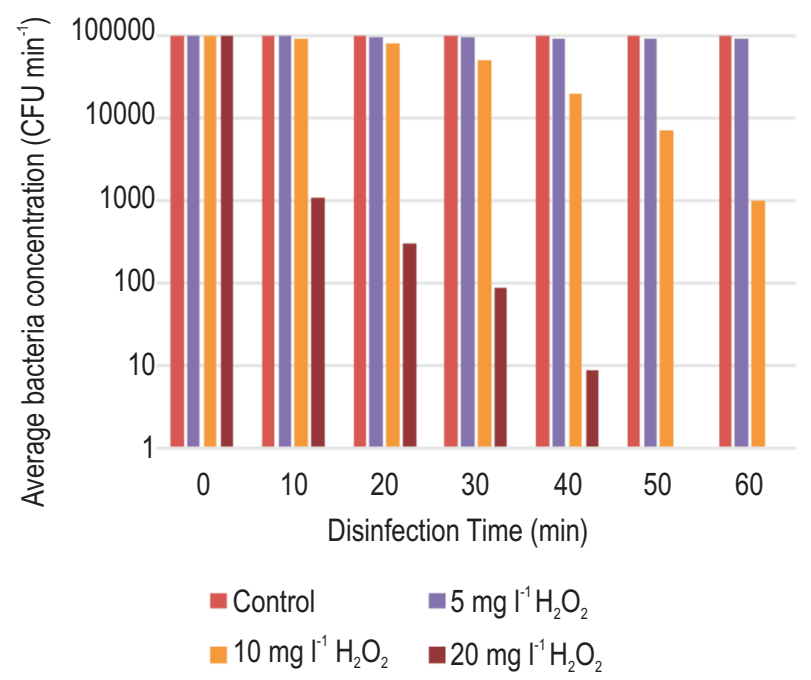

Fig. 4 : Effect of hydrogen peroxide concentration on the Escherichia coli disinfection process $\left(5,10\right.$ and $20 \mathrm{mg} \mathrm{l}^{-1} \mathrm{H}_{2} \mathrm{O}_{2} ; 1 \times 10^{5} \mathrm{CFU} \mathrm{ml^{-1 }}$ of Escherichia coliand 60 min disinfection period under batch conditions)

Mason et al., 2003; Mason et al., 2003; Gogate, 2008). In addition, it was determined that the presence of sulphate ions from the ions accompanying the system increases ultrasonic etching on steel and metal surfaces more than bicarbonate and chloride ions (Jiang et al., 2006). In addition, whether the energy, as a result of the attenuation of the cavitation of other media ions, reduces the effectiveness of this disinfection process using a variety of different mechanisms must be examined. Silva et al., 2007), reported maximum efficiency of reduction of nitrate ions to nitrite accompanied by various catalysts was $68 \%$. Furthermore, 


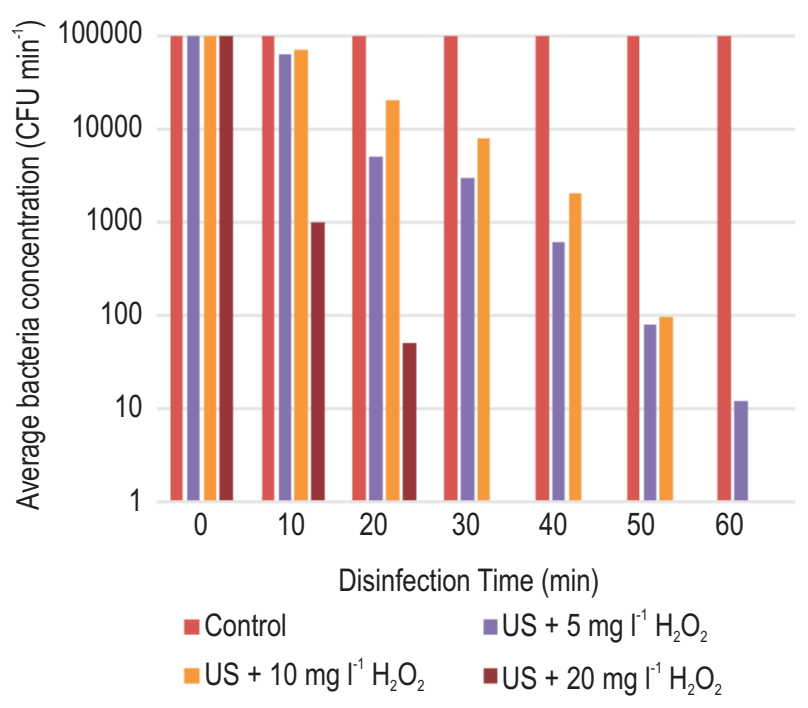

Fig. 5 : Effect of hydrogen peroxide concentration on the ultrasonic disinfection process (an ultrasonic frequency of $28 \mathrm{kHz}$ and $100 \mathrm{~W}$ power at 5,10 and $20 \mathrm{mg} \mathrm{l}^{-1} \mathrm{H}_{2} \mathrm{O}_{2} ; 1 \times 10^{5} \mathrm{CFU} \mathrm{ml^{-1 }}$ Escherichia coli and $60 \mathrm{~min}$ disinfection period under batch conditions)

it was observed that the efficiency of nitrite formation was $92 \%$ if the reduction process took place in an ultrasonic process.

The effect of dissolved nitrogen gas on the ultrasonic disinfection process is shown in Fig. 3. The inactivation rate of $E$. coli resulting in disinfection was performed at $8 \mathrm{I} \mathrm{hr}^{-1}, 12 \mathrm{I} \mathrm{hr}^{-1}$ and $16 \mathrm{I} \mathrm{hr}$ rates of $\mathrm{N}_{2}$ gas flow were $5 \mathrm{log}$ after a disinfection period of $60 \mathrm{~min}$. The amount of nitrogen gas dissolved in the liquid affected the production of collapse and accelerated bacterial inactivation due to modification of adiabatic rate, thermal transmission and surface tension of liquid and altering the hot spot temperature of micro-bubbles (Rooze et al., 2013). The result of hydrogen peroxide disinfection studies is shown in Fig. 4.

5, 10 and $20 \mathrm{mg} \mathrm{l}^{-1} \mathrm{H}_{2} \mathrm{O}_{2}$ were used to inactivate Escherichia coli, then $0.05-\log$ after $60 \mathrm{~min}, 2-\log$ after $60 \mathrm{~min}$ and $5-\log$ after 50 min disinfection efficiency was attained respectively. These results showed that increasing the hydrogen peroxide concentration raise the bacterial inactivation ratio as expected. The disinfection study performed in an ultrasonic reactor with addition of $5 \mathrm{mg} \mathrm{l}^{-1}, 10 \mathrm{mg} \mathrm{l}^{-1}$ and $20 \mathrm{mg} \mathrm{l}^{-1}$ of $\mathrm{H}_{2} \mathrm{O}_{2}$ during a 60 min disinfection period is shown in Fig. 5. When ultrasound was performed with $5 \mathrm{mg} \mathrm{l}^{-1}, 10 \mathrm{mg} \mathrm{l}^{-1}$ or $20 \mathrm{mg} \mathrm{l}^{-1} \mathrm{H}_{2} \mathrm{O}_{2}$ concentration, the disinfection efficiency of Escherichia coli was $3.92 \log$ after $60 \mathrm{~min}, 5 \log$ after $60 \mathrm{~min}$ and $5 \log$ after $30 \mathrm{~min}$, respectively. This indicates that Escherichia coli disinfection with hydrogen peroxide and ultrasound decreased the disinfection period according to a single hydrogen peroxide application. The physical effects of low-frequency ultrasound improved the bacterial inactivation ratio by enhancing the disinfection effect of

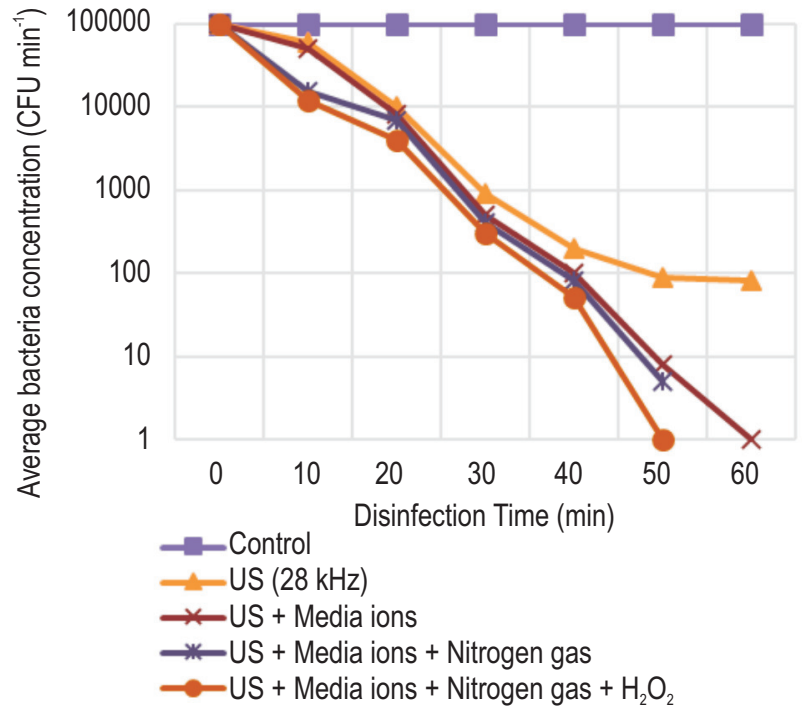

Fig. 6 : Effect of media ions, dissolved nitrogen gas and hydrogen peroxide on the ultrasonic disinfection process (an ultrasonic frequency of $28 \mathrm{kHz}$ and $100 \mathrm{~W}$ of power at $200 \mathrm{mgl}^{-1} \mathrm{SO}_{4}^{-2}, 50 \mathrm{mg} \mathrm{l}^{-1} \mathrm{HCO}_{3}, 50 \mathrm{mg} \mathrm{l}^{-1}$

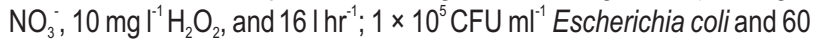
min disinfection period under batch conditions)

hydrogen peroxide through synergistic effects of ultrasound. These results indicate that ultrasound and hydrogen peroxide reduced the concentration of hydrogen peroxide concentration to obtain an eligible bacterial inactivation efficiency in water because ultrasound accelerates the contact of $\mathrm{OH}^{-}$and $\mathrm{H}^{+}$ radicals, which are the decomposition products of $\mathrm{H}_{2} \mathrm{O}_{2}$ with bacteria.

The simultaneous effect of media ions, dissolved nitrogen gas and hydrogen peroxide in the ultrasonic reactors is shown in Fig. 6. If ultrasound frequency was applied with $200 \mathrm{mgl}^{-1} \mathrm{SO}_{4}^{-2} ; 50$ $\mathrm{mgl}^{-1} \mathrm{HCO}_{3} ; 50 \mathrm{mgl}^{-1} \mathrm{NO}_{3} ; 10 \mathrm{mg} \mathrm{I}^{-1} \mathrm{H}_{2} \mathrm{O}_{2}$ and $16 \mathrm{I} \mathrm{hr}^{-1}$ nitrogen gas the disinfection efficiency of Escherichia coli increased 2 log from ultrasonic frequency alone for $50 \mathrm{~min}$.

In this study, it was observed that sulphate and bicarbonate ions had a considerable effect on the ultrasonic disinfection process and the nitrogen dissolved in water had a favourable effect on ultrasonic disinfection. In addition, this study demonstrated that ultrasound and hydrogen peroxide created a synergy to achieve an adequate water disinfection efficiency. The treatment process of both hydrogen peroxide and ultrasound indicated that the synergistic effect was superior to simple ultrasound alone.

\section{Acknowledgment}

This study was supported by the Anadolu University Scientific Research Projects Commission under grant number $1202 F 028$. 


\section{References}

Arbuckle, J.G.J., M.A. Miller and M.L. Sullivan, T.F.P.: Environmental Law Handbook. United States, Government Institutes, Inc., Washington DC (1976).

Arnal, J., M. Sancho, G. Verdú, J. Lora, J. Marin and J. Cháfer: Selection of the most suitable ultrafiltration membrane for water disinfection in developing countries. Desalination, 168, 265-270 (2004).

Blume, T. and U. Neis: Improved wastewater disinfection by ultrasonic pre-treatment. Ultrasonics Sonochemistry, 11, 333-336 (2004).

Chen, J.J. and H.H. Yeh: The mechanisms of potassium permanganate on algae removal. Water Res., 39, 4420-4428 (2005).

Drogui, P., S. Elmaleh, M. Rumeau, C. Bernard and A. Rambaud: Hydrogen peroxide production by water electrolysis: application to disinfection. J. Appl. Electrochemi., 31, 877-882 (2001).

Fiessinger, F., Y. Richard, A. Montiel and P. Musquere: Advantages and disadvantages of chemical oxidation and disinfection by ozone and chlorine dioxide. Sci. Total Environ., 18, 245-261 (1981).

Giannakis, S., S. Papoutsakis, E. Darakas, A. Escalas-Cañellas, C. Pétrier and C. Pulgarin: Ultrasound enhancement of near-neutral photo-Fenton for effective $E$. coli inactivation in wastewater. Ultrasonics Sonochemistry, 22, 515-546 (2015).

Gogate, P.R.: Cavitational reactors for process intensification of chemical processing applications: A critical review. Chemical Engineering and Processing: Process Intensification, 47, 515-527 (2008)

Gómez-López, V.M., M.I. Gil, A. Allende, J. Blancke, L. Schouteten and M.V. Selma: Disinfection capacity of high-power ultrasound against $E$. coli $0157: \mathrm{H} 7$ in process water of the fresh-cut industry. Food Biopro. Tech., 7, 3390-3397 (2014).

Gray, N.: Pathogen Control in Drinking Water. Microbiology of Waterborne Diseases, Elsevier Ltd., pp. 537-569 (2014).

Hulsmans, A., K. Joris, N. Lambert, H. Rediers, P. Declerck, Y. Delaedt, F. Ollevier and S. Liers: Evaluation of process parameters of ultrasonic treatment of bacterial suspensions in a pilot scale water disinfection system. Ultrasonics Sonochemistry, 17, 1004-1009 (2010).

Ince, N.H. and R. Belen: Aqueous phase disinfection with power ultrasound: Process kinetics and effect of solid catalysts. Environ. Sci. Technol., 35, 1885-1888 (2001).

Jiang, S. L., Y. G. Zheng and Z. M. Yao: Cavitation erosion behavior of $20 \mathrm{SiMn}$ low alloy steel in $\mathrm{Na}_{2} \mathrm{SO}_{4}$ and $\mathrm{NaHCO}_{3}$ solutions. Corr. Sci., 48, 2614-2632 (2006).

Joyce, E., T. Mason, S. Phull and J. Lorimer: The development and evaluation of electrolysis in conjunction with power ultrasound for the disinfection of bacterial suspensions. Ultrasonics Sonochemistry, 10, 231-234 (2003).

Krishnan, R.R., K. Dharmaraj and B.R. Kumari: A comparative study on the physico-chemical and bacterial analysis of drinking, borewell and sewage water in three different places of Sivakasi. J. Environ. Biol., 28, 105-108 (2007).

LeChevallier, M.W. and K.K. Au: Water Treatment and Pathogen Control: Process Efficiency in Achieving Safe Drinking-water. Water Intelligence Online, 12, 9781780405858 (2013).

Li, Q., S. Mahendra, D.Y. Lyon, L. Brunet, M.V. Liga, D. Li and P.J. Alvarez: Antimicrobial nanomaterials for water disinfection and microbial control: Potential applications and implications. Water Res., 42, 4591-4602 (2008).

Mason, T., H. Duckhouse, E. Joyce and J. Lorimer: Uses of ultrasound in the biological decontamination of water. $5^{\text {th }}$ World Congress on Ultrasonics (WCU). Paris, France (2003).

Mason, T., E. Joyce, S. Phull and J. Lorimer: Potential uses of ultrasound in the biological decontamination of water. Ultrasonics Sonochemistry, 10, 319-323 (2003).

Nair, G.A., J.A. Bohjuari, M.A. Al-Mariami, F.A. Attia and F. El-Touml: Groundwater quality of North-East Libya. J. Environ. Biol., 27, 695700 (2006).

Phull, S., A. Newman, J. Lorimer, B. Pollet and T. Mason: The development and evaluation of ultrasound in the biocidal treatment of water. Ultrasonics Sonochemistry, 4, 157-164 (1997).

Prakash, K. and R. Somashekar: Groundwater quality- Assessment on Anekal Taluk, Bangalore urban district, India. J. Environ. Biol., 27, 633-637 (2006).

Rooze, J., E.V. Rebrov, J.C. Schouten and J.T. Keurentjes: Dissolved gas and ultrasonic cavitation-a review. Ultrasonics Sonochemistry, 20, 1-11 (2013).

Scherba, G., R. Weigel and W.D. O'Brien: Quantitative assessment of the germicidal efficacy of ultrasonic energy. Appl. Environ. Microbiol., 57, 2079-2084 (1991).

Silva, L. A., M. Korn and J. B. de Andrade: Influence of ultrasonic waves in the reduction of nitrate to nitrite by hydrazine-Cu (II). Ultrasonics Sonochemistry, 14, 275-280 (2007).

Spellman, F.R.: Choosing disinfection alternatives for water/wastewater treatment plants. CRC Press (1999).

Tauber, A., H.P. Schuchmann and C. Von Sonntag: Sonolysis of aqueous 4-nitrophenol at low and high ph. Ultrasonics Sonochemistry, 7, 45-52 (2000).

Von Gunten, U.: Ozonation of drinking water: Part II. Disinfection and byproduct formation in presence of bromide, iodide or chlorine. Water Res., 37, 1469-1487 (2003).

Von Gunten, U. and U. Pinkernell: Ozonation of bromide-containing drinking waters: A delicate balance between disinfection and bromate formation. Water Sci. Technol., 41, 53-59 (2000).

Wu, T.Y., N. Guo, C.Y. Teh and J.X.W. Hay: Efficiency Issues for Ultrasound. Adv. Ultrasound Technol. Environ. Remed., doi. org/10.1007/978-94-007-5533-8-4 (2013). 